\title{
Dietary Cation-Anion Difference and Dietary Protein Effects on Performance and Acid-Base Status of Dairy Cows in Early Lactation ${ }^{1}$
}

\author{
W. Hu${ }^{\star 2,3}$ M. R. Murphy, ${ }^{*}$ P. D. Constable, $\dagger^{4}$ and E. Block \\ ${ }^{*}$ Department of Animal Sciences, University of Illinois, Urbana 61801 \\ †Department of Veterinary Clinical Medicine, University of Illinois, Urbana 61802 \\ ¥Arm \& Hammer Animal Nutrition Group, Church \& Dwight Co. Inc., Princeton, NJ 08543
}

\begin{abstract}
Our objective was to examine the effects of dietary cation-anion difference (DCAD) with different concentrations of dietary crude protein $(\mathrm{CP})$ on performance and acid-base status in early lactation cows. Six lactating Holstein cows averaging $44 \mathrm{~d}$ in milk were used in a $6 \times 6$ Latin square design with a $2 \times 3$ factorial arrangement of treatments: DCAD of $-3,22$, or 47 milliequivalents $(\mathrm{Na}+\mathrm{K}-\mathrm{Cl}-\mathrm{S}) / 100 \mathrm{~g}$ of dry matter (DM), and 16 or $19 \% \mathrm{CP}$ on a DM basis. Linear increases with DCAD occurred in DM intake, milk fat percentage, $4 \%$ fat-corrected milk production, milk true protein, milk lactose, and milk solids-not-fat. Milk production itself was unaffected by DCAD. Jugular venous blood $\mathrm{pH}$, base excess and $\mathrm{HCO}_{3}{ }^{-}$concentration, and urine $\mathrm{pH}$ increased, but jugular venous blood $\mathrm{Cl}^{-}$concentration, urine titratable acidity, and net acid excretion decreased linearly with increasing DCAD. An elevated ratio of coccygeal venous plasma essential AA to nonessential AA with increasing DCAD indicated that $\mathrm{N}$ metabolism in the rumen was affected, probably resulting in more microbial protein flowing to the small intestine. Cows fed $16 \% \mathrm{CP}$ had lower urea $\mathrm{N}$ in milk than cows fed $19 \% \mathrm{CP}$; the same was true for urea $\mathrm{N}$ in coccygeal venous plasma and urine. Dry matter intake, milk production, milk composition, and acid-base status did not differ between the 16 and 19\% CP treatments. It was concluded that DCAD affected DM intake and performance of dairy cows in early lactation. Feeding $16 \%$
\end{abstract}

Received August 7, 2006

Accepted March 20, 2007.

${ }^{1}$ Supported by Illinois Experiment Station NE-132 "Environmental and Economic Impacts of Nutrient Management on Dairy Forage Systems" and Church \& Dwight Co. Inc., Arm \& Hammer Animal Nutrition Group, Princeton, NJ.

${ }^{2}$ Corresponding author: whu@udel.edu

${ }^{3}$ Current address: Department of Animal and Food Sciences, University of Delaware, Newark, DE 19716.

${ }^{4}$ Current address: Department of Veterinary Clinical Sciences, Purdue University, 625 Harrison Street, West Lafayette, IN 47907. dietary CP to cows in early lactation, compared with $19 \%$ CP, maintained lactation performance while reducing urea $\mathrm{N}$ excretion in milk and urine.

Key words: dietary cation-anion difference, dietary protein, performance, acid-base status

\section{INTRODUCTION}

With the increased use of the DCAD concept in dry cow nutrition, interest has also grown in the potential effects of DCAD on lactating dairy cows. Tucker et al. (1988) were the first to evaluate DCAD with lactating dairy cows, and their results indicated that there might be an optimal DCAD for achieving maximal intake and milk production. Other studies (West et al., 1991, 1992; Delaquis and Block, 1995a,b) also suggested that DCAD had a significant influence on acid-base status and lactation performance of dairy cows. It appeared that DCAD improved acid-base balance and was positively related to productive performance in lactating dairy cows (Sanchez and Beede, 1996; Hu and Murphy, 2004). However, more research is needed before specific recommendations can be made regarding optimal DCAD for lactating dairy cows because a DCAD recommendation can be affected by numerous factors, including feed intake, acid-producing potential of the diet, and concentrations of other fixed ions (Sanchez et al., 2000). Wildman et al. (2003) reported that milk yield tended $(P=$ $0.09)$ to be affected by an interaction of DCAD $(\mathrm{Na}+\mathrm{K}$ $-\mathrm{Cl}$ ) and dietary protein concentration in dairy cows in late lactation (225 DIM) during hot weather.

The potential interaction of DCAD and dietary protein should be further evaluated, especially with cows in early lactation, before recommending an optimum DCAD for high-producing dairy cows. Amino acid metabolism and acid-base homeostasis are intimately related (Patience, 1990). Renal and hepatic nitrogen metabolism are linked by an interorgan glutamine flux, coupling both renal ammoniagenesis and hepatic urea production to systemic acid-base regulation (Guder et al., 1987). Supplemental protein might play a role in the 
systemic buffering of a chronic acid load in ruminants (Galyean, 1996). Little information is available on the role of supplemental protein in providing a supply of both AA and ammonia for systemic buffering of cows in early lactation. The interaction of these variables is also of interest because decreased protein concentrations in the diet are frequently recommended to reduce environmental impacts of the dairy industry.

Our objective was to examine the effects of altering DCAD with different concentrations of dietary protein on acid-base status, mineral and $\mathrm{N}$ metabolism, and milk production and composition of cows in early lactation. The interaction of DCAD and dietary protein, and the potential role of dietary protein in systemic acidbase regulation were also evaluated.

\section{MATERIALS AND METHODS}

\section{Experimental Design and Animal Care}

Six multiparous Holstein cows averaging 44 DIM were assigned randomly to a $6 \times 6$ Latin square with a $2 \times 3$ factorial arrangement of treatments: DCAD of $-3,22$, or $47 \mathrm{mEq}(\mathrm{Na}+\mathrm{K}-\mathrm{Cl}-\mathrm{S}) / 100 \mathrm{~g}$ of $\mathrm{DM}$, and 16 or $19 \% \mathrm{CP}$ on a DM basis. Each experimental period consisted of a 2 -wk adjustment period followed by a 1wk collection period. Cows were housed in tie stalls indoors except during milking and during exercise period on a dirt lot between the a.m. milking and feeding. Feed offered was adjusted daily and $110 \%$ of consumption the previous day (as-fed basis) was provided at 1100 and $1630 \mathrm{~h}$. Water was available for ad libitum consumption. Cows were milked twice daily at approximately 0600 and $1500 \mathrm{~h}$.

The TMR was composed of $50 \%$ concentrate mix of mainly cracked corn-soybean meal and 50\% conventional corn silage on a DM basis. Two concentrations of protein in the diets were achieved by varying amounts of soybean meal and corn; DCAD was varied by using $\mathrm{CaCl}_{2}, \mathrm{~K}_{2} \mathrm{CO}_{3}$, or $\mathrm{NaHCO}_{3}$ in the concentrate mix (Table 1). An analysis of TMR particle size by dry sieving (Murphy and Zhu, 1997) found that $15.9 \%$ was $>6.3 \mathrm{~mm}, 24.0 \%>4.75 \mathrm{~mm}, 35.7 \%>3.35 \mathrm{~mm}, 44.5 \%$ $>2.36 \mathrm{~mm}, 55.3 \%>1.7 \mathrm{~mm}$, and $71.1 \%>1.18 \mathrm{~mm}$; therefore, average particle size was $2.1 \mathrm{~mm}$ and the $\log _{10}$ standard deviation was 0.49 .

\section{Sample Collection and Analysis}

Drinking Water. Drinking water was collected in $1,000-\mathrm{mL}$ containers weekly; the water samples were stored at $-15^{\circ} \mathrm{C}$ until the end of the experiment and then composited and pooled for mineral analysis (Dairy One Forage Laboratory, Ithaca, NY). Drinking water analysis indicated (per kg) $41.8 \mathrm{mg}$ of $\mathrm{Na},<0.1 \mathrm{mg}$ of
$\mathrm{K}, 12.0 \mathrm{mg}$ of $\mathrm{Cl}, 0.0 \mathrm{mg}$ of $\mathrm{S}, 17.1 \mathrm{mg}$ of $\mathrm{Ca}, 0.1 \mathrm{mg}$ of $\mathrm{P}$, and $13.3 \mathrm{mg}$ of $\mathrm{Mg}$, which suggested that the mineral intake from drinking water had little effect on total mineral intake.

Feeds and Orts. Feed intake of each cow was recorded from d 16 to 20 of each experimental period; thus, samples of feed and orts were collected daily during this period. Orts were weighed and sampled before the a.m. feeding. Feed and orts samples were dried in a forced-air oven at $55^{\circ} \mathrm{C}$ until constant weights were obtained. Weekly samples of corn silage, concentrate mix, and the TMR were stored at $-15^{\circ} \mathrm{C}$ until the end of the experiment, and then composited and pooled for later analysis. Nutrient contents of corn silage, concentrate, and the TMR were analyzed by wet chemistry for $\mathrm{DM}, \mathrm{CP}, \mathrm{ADF}, \mathrm{NDF}$, and minerals (Dairy One Forage Laboratory). Also, energy concentration was calculated (Dairy One Forage Laboratory). The nutrient composition presented in Table 1 was based on calculation from the nutrient content analysis of corn silage and concentrate.

Urine. On d 19 of each experimental period, cows were manually stimulated to urinate at $0900 \mathrm{~h}$, and midstream urine was collected in $50-\mathrm{mL}$ plastic container. Urine $\mathrm{pH}$ was measured immediately. Urine samples (30 $\mathrm{mL}$ for each cow) were stored at $-15^{\circ} \mathrm{C}$ until further analyzed. Urine concentrations of $\mathrm{Na}^{+}, \mathrm{K}^{+}$, and $\mathrm{Cl}^{-}$were determined using an ion-selective electrode; urine $\mathrm{Ca}$, urea $\mathrm{N}$, and creatinine were measured spectrophotometrically. All of these assays were performed on the Hitachi 917 analyzer (Roche, Indianapolis, IN) using Roche diagnostic reagents.

Urine titratable acidity (TA) and ammonium concentrations were determined by titration of urine samples with $0.1 \mathrm{~N} \mathrm{NaOH}$, which was standardized by potassium biphthalate (Chan, 1972). Net acid excretion (NAE) was the sum of urine TA and ammonium; the urine TA measured was actually the amount of urinary TA minus $\mathrm{HCO}_{3}{ }^{-}$(Chan, 1972). Urinary mineral excretions $\left(\mathrm{Ca}, \mathrm{Na}^{+}, \mathrm{K}^{+}\right.$, and $\left.\mathrm{Cl}^{-}\right)$were expressed as minerals to creatinine concentration to overcome variations in urine volume among animals.

Blood. On d 20 of each experimental period, immediately before the a.m. feeding, $5 \mathrm{~mL}$ of jugular venous blood was collected anaerobically with a plastic syringe containing lithium heparin, capped, placed on crushed ice, and analyzed for $\mathrm{pH}$, partial pressure of $\mathrm{CO}_{2}$ $\left(\mathbf{p C O} \mathbf{O}_{2}\right)$, partial pressure of $\mathrm{O}_{2}\left(\mathbf{p O}_{2}\right), \mathrm{HCO}_{3}{ }^{-}$, and base excess in a blood gas analyzer (Rapidlab 850 system, Bayer Diagnostics, Tarrytown, NY) within 2 h. Simultaneously, $\mathrm{Na}^{+}, \mathrm{K}^{+}, \mathrm{Cl}^{-}$, and $\mathrm{Ca}^{2+}$ were determined using ion-selective electrode, and anion gap was calculated by using the blood gas analyzer (Rapidlab 850 system, Bayer Diagnostics). Values of $\mathrm{pH}, \mathrm{pCO}_{2}$, and $\mathrm{pO}_{2}$ were 
Table 1. Ingredients and nutrient composition in experimental diets (DM basis) combining 3 levels of DCAD with 2 levels of $\mathrm{CP}$

\begin{tabular}{|c|c|c|c|c|c|c|}
\hline & \multicolumn{2}{|c|}{$\mathrm{DCAD}^{1}=-3$} & \multicolumn{2}{|c|}{$\mathrm{DCAD}=22$} & \multicolumn{2}{|c|}{$\mathrm{DCAD}=47$} \\
\hline & $16 \% \mathrm{CP}$ & $19 \% \mathrm{CP}$ & $16 \% \mathrm{CP}$ & $19 \% \mathrm{CP}$ & $16 \% \mathrm{CP}$ & $19 \% \mathrm{CP}$ \\
\hline \multicolumn{7}{|l|}{ Ingredient (\%) } \\
\hline Corn silage $^{2}$ & 50.0 & 50.0 & 50.0 & 50.0 & 50.0 & 50.0 \\
\hline Corn grain, cracked & 26.5 & 18.5 & 26.9 & 18.5 & 24.5 & 17.0 \\
\hline Soybean meal, $48 \%$ & 19.6 & 27.7 & 19.6 & 27.7 & 20.3 & 28.1 \\
\hline $\mathrm{NaCl}$ & 0.59 & 0.59 & 0.34 & 0.34 & 0.34 & 0.34 \\
\hline Dicalcium phosphate & 0.99 & 0.99 & 0.99 & 0.99 & 0.84 & 0.64 \\
\hline $\mathrm{MgO}$ & 0.09 & 0.09 & 0.09 & 0.09 & 0.09 & 0.09 \\
\hline Limestone & 1.16 & 1.06 & 1.10 & 1.52 & 1.06 & 1.06 \\
\hline $\mathrm{CaCl}_{2}$ & 0.85 & 0.97 & 0.00 & 0.00 & 0.00 & 0.00 \\
\hline $\mathrm{NaHCO}_{3}$ & 0.00 & 0.00 & 0.42 & 0.42 & 1.23 & 1.35 \\
\hline $\mathrm{K}_{2} \mathrm{CO}_{3}$ & 0.00 & 0.00 & 0.36 & 0.23 & 1.46 & 1.21 \\
\hline Mineral and vitamin premix ${ }^{3}$ & 0.19 & 0.19 & 0.19 & 0.19 & 0.19 & 0.19 \\
\hline \multicolumn{7}{|l|}{ Composition } \\
\hline $\mathrm{CP}, \%$ & 15.7 & 19.7 & 16.0 & 19.4 & 16.3 & 19.9 \\
\hline $\mathrm{NE}_{\mathrm{L}}, \mathrm{Mcal} / \mathrm{kg}$ & 1.69 & 1.68 & 1.69 & 1.69 & 1.66 & 1.64 \\
\hline $\mathrm{ADF}, \%$ & 15.1 & 15.1 & 15.1 & 14.7 & 15.4 & 15.2 \\
\hline $\mathrm{NDF}, \%$ & 26.7 & 26.5 & 26.6 & 26.3 & 26.3 & 27.1 \\
\hline $\mathrm{NFC}, 4 \%$ & 48.3 & 49.0 & 49.1 & 49.5 & 48.4 & 46.3 \\
\hline $\mathrm{Na}, \%$ & 0.27 & 0.25 & 0.31 & 0.29 & 0.54 & 0.63 \\
\hline $\mathrm{K}, \%$ & 1.05 & 1.22 & 1.21 & 1.28 & 1.76 & 1.85 \\
\hline $\mathrm{Cl}, \%$ & 1.19 & 1.07 & 0.44 & 0.41 & 0.38 & 0.39 \\
\hline $\mathrm{S}, \%$ & 0.19 & 0.21 & 0.18 & 0.20 & 0.17 & 0.20 \\
\hline $\mathrm{Ca}, \%$ & 1.49 & 1.46 & 1.16 & 1.23 & 1.09 & 1.00 \\
\hline $\mathrm{P}, \%$ & 0.59 & 0.64 & 0.60 & 0.59 & 0.58 & 0.56 \\
\hline $\mathrm{Mg}, \%$ & 0.26 & 0.28 & 0.27 & 0.28 & 0.27 & 0.28 \\
\hline DCAD, $\mathrm{mEq} / 100 \mathrm{~g}$ of $\mathrm{DM}$ & -6.6 & -0.8 & 20.5 & 21.8 & 47.5 & 51.1 \\
\hline
\end{tabular}

${ }^{1} \mathrm{DCAD}$ in milliequivalents of $(\mathrm{Na}+\mathrm{K}-\mathrm{Cl}-\mathrm{S}) / 100 \mathrm{~g}$ of $\mathrm{DM}$.

${ }^{2}$ Contained $37.1 \% \mathrm{DM}, 44.0 \% \mathrm{NDF}, 25.0 \% \mathrm{ADF}$, and $6.0 \% \mathrm{CP}$ on a DM basis.

${ }^{3}$ Contained $5.00 \% \mathrm{Mg}, 10.00 \% \mathrm{~S}, 7.50 \% \mathrm{~K}, 2.00 \% \mathrm{Fe}, 3.00 \% \mathrm{Zn}, 3.00 \% \mathrm{Mn}, 5,000.0 \mathrm{mg} / \mathrm{kg} \mathrm{Cu}, 250.0 \mathrm{mg} /$ $\mathrm{kg} \mathrm{I}, 40.0 \mathrm{mg} / \mathrm{kg} \mathrm{Co}, 150.0 \mathrm{mg} / \mathrm{kg}$ Se, 2,205,000 IU/kg Vitamin A, 661,500 IU/kg Vitamin $\mathrm{D}_{3}$, and 22,050 IU/kg Vitamin E.

${ }^{4} \mathrm{NFC}=100-\mathrm{CP}-$ fat $-\mathrm{NDF}-$ ash.

corrected for rectal temperature. Coccygeal venous blood (there might be a slight chance for arterial blood to be included in the blood sample, but venous blood is referred to herein) was also collected using a Vacutainer (Becton Dickinson, Franklin Lakes, NJ) containing lithium heparin, placed on crushed ice, and subjected immediately to centrifugation at $1,500 \times g$ for $15 \mathrm{~min}$. Plasma was then retrieved, transferred to 5 -mL plastic tubes, and frozen at $-15^{\circ} \mathrm{C}$ until analyzed.

Coccygeal venous plasma samples were prepared for AA determination; individual AA and ammonia were then separated by ion-exchange chromatography (Beckman 6300 amino acid analyzer, Beckman Instruments Inc., Palo Alto, CA). Coccygeal venous plasma samples were analyzed for $\mathrm{Na}^{+}, \mathrm{K}^{+}, \mathrm{Cl}^{-}, \mathrm{Ca}$, urea $\mathrm{N}$, and creatinine using the same analytical methods as for the urine.

Milk Production and $\boldsymbol{B W}$. Milk production was measured at 0600 and $1500 \mathrm{~h}$ daily. On d 21 of each experimental period, milk samples were collected from consecutive p.m. and a.m. milking, composited based on p.m. and a.m. milk production, and analyzed for milk fat, true protein, lactose, SNF, SCC, and urea $\mathrm{N}$ using a Milkoscan System 4000 (Foss North American, Eden Prairie, MN) by an infrared method (Dairy Lab Services, Dubuque, IA). Also, milk samples from the a.m. milking were collected, refrigerated at $4^{\circ} \mathrm{C}$, and measured for $\mathrm{pH}$ within $2 \mathrm{~h}$. Although BW was determined at the start of the trial and weekly thereafter, only BW measured during the last week of each experimental period were included in statistical analyses.

\section{Statistical Analysis}

During the last experimental period, one cow was treated for mastitis; therefore, samples were not collected from her during that period.

The DMI from d 16 to 20 and milk yield from d 15 to 21 in each experimental period were reduced to means for each cow. Jugular venous blood, urine, and milk $\mathrm{pH}$ were converted to free $\mathrm{H}^{+}$concentration $\left(\left[\mathrm{H}^{+}\right]\right.$, assuming an activity coefficient of 1 ) and subjected to statistical analysis (Murphy, 1982). The resulting mean $\left[\mathrm{H}^{+}\right]$could still be transformed for convenience and reported as $\mathrm{pH}$. Therefore, each mean was presented as 
Table 2. Least squares means for DMI, BW, milk yield, $4 \%$ FCM, and milk composition in experimental diets combining 3 levels of DCAD with 2 levels of $\mathrm{CP}$

\begin{tabular}{|c|c|c|c|c|c|c|c|c|c|c|c|c|}
\hline \multirow[b]{2}{*}{ Variable } & \multicolumn{2}{|c|}{$\mathrm{DCAD}^{1}=-3$} & \multicolumn{2}{|c|}{$\mathrm{DCAD}=22$} & \multicolumn{2}{|c|}{$\mathrm{DCAD}=47$} & \multirow[b]{2}{*}{ SE } & \multicolumn{5}{|c|}{ Orthogonal contrast $^{2}$} \\
\hline & $16 \% \mathrm{CP}$ & $19 \% \mathrm{CP}$ & $16 \% \mathrm{CP}$ & $19 \% \mathrm{CP}$ & $16 \% \mathrm{CP}$ & $19 \% \mathrm{CP}$ & & A & B & $\mathrm{C}$ & $\mathrm{D}$ & $\mathrm{E}$ \\
\hline DMI, kg/d & 24.9 & 23.9 & 26.1 & 25.7 & 27.0 & 28.2 & 1.9 & $\mathrm{NS}^{3}$ & $<0.01$ & NS & NS & NS \\
\hline $\mathrm{BW}, \mathrm{kg}$ & 678 & 675 & 680 & 677 & 682 & 678 & 12 & NS & NS & NS & NS & NS \\
\hline $\begin{array}{l}\text { Milk } \\
\text { Yield, kg/d }\end{array}$ & & & & & & & & & & & & \\
\hline $\begin{array}{l}\text { Yield, kg/d } \\
4 \% \text { FCM, kg/d }\end{array}$ & 35.3 & 36.7 & 36.4 & 35.8 & 36.1 & 36.6 & 2.3 & NS & NS & NS & NS & $\begin{array}{l}\text { NS } \\
\text { NS }\end{array}$ \\
\hline $\begin{array}{l}4 \% \text { FCM, kg/d } \\
\text { Fat, \% }\end{array}$ & 31.1 & 30.3 & 32.4 & 33.1 & 33.9 & 34.5 & 2.7 & NS & 0.01 & NS & NS & $\begin{array}{l}\text { NS } \\
\text { NS }\end{array}$ \\
\hline $\begin{array}{l}\text { Fat, \% } \\
\text { Fat, kg/d }\end{array}$ & $\begin{array}{l}3.12 \\
1.12\end{array}$ & $\begin{array}{l}2.85 \\
1.04\end{array}$ & $\begin{array}{l}3.27 \\
1.19\end{array}$ & $\begin{array}{l}3.46 \\
1.25\end{array}$ & $\begin{array}{l}3.57 \\
1.29\end{array}$ & $\begin{array}{l}3.62 \\
132\end{array}$ & $\begin{array}{l}0.50 \\
0.17\end{array}$ & $\begin{array}{l}\text { NS } \\
\text { NS }\end{array}$ & $\begin{array}{l}0.02 \\
0.01\end{array}$ & $\begin{array}{l}\text { NS } \\
\text { NS }\end{array}$ & $\begin{array}{l}\text { NS } \\
\text { NS }\end{array}$ & $\begin{array}{l}\mathrm{NS} \\
\mathrm{NS}\end{array}$ \\
\hline Protein, \% & 3.12 & 3.09 & 3.20 & 3.16 & 3.24 & 3.24 & 0.09 & NS & $<0.01$ & NS & NS & NS \\
\hline Protein, kg/d & 1.10 & 1.11 & 1.15 & 1.11 & 1.15 & 1.18 & 0.07 & NS & 0.07 & NS & NS & $\mathrm{N}$ \\
\hline Lactose, $\%$ & 4.79 & 4.82 & 4.78 & 4.79 & 4.90 & 4.90 & 0.09 & NS & 0.03 & 0.05 & NS & NS \\
\hline Lactose, $\mathrm{kg} / \mathrm{d}$ & 1.69 & 1.76 & 1.74 & 1.72 & 1.78 & 1.80 & 0.12 & NS & NS & NS & NS & NS \\
\hline $\mathrm{SNF}, \%$ & 8.58 & 9.01 & 9.11 & 8.98 & 9.09 & 8.82 & 0.13 & NS & $<0.01$ & NS & NS & NS \\
\hline $\mathrm{SNF}, \mathrm{kg} / \mathrm{d}$ & 3.18 & 3.21 & 3.22 & 3.17 & 3.27 & 3.31 & 0.21 & NS & NS & NS & NS & NS \\
\hline Urea, mg of $\mathrm{N} / \mathrm{dL}$ & 17.0 & 21.0 & 13.7 & 21.5 & 13.7 & 19.5 & 2.24 & $<0.01$ & 0.02 & NS & NS & 0.08 \\
\hline $\mathrm{SCC}, \times 1,000 / \mathrm{mL}$ & 46 & 34 & 37 & 36 & 38 & 31 & 19 & NS & NS & NS & NS & NS \\
\hline
\end{tabular}

${ }^{1} \mathrm{DCAD}$ in milliequivalents of $(\mathrm{Na}+\mathrm{K}-\mathrm{Cl}-\mathrm{S}) / 100 \mathrm{~g}$ of DM.

${ }^{2} \mathrm{~A}=16 \% \mathrm{CP}$ vs. $19 \% \mathrm{CP} ; \mathrm{B}=$ linear effect of $\mathrm{DCAD} ; \mathrm{C}=$ quadratic effect of DCAD; $\mathrm{D}=$ interaction between $\mathrm{CP}$ concentration and linear effect of DCAD; $\mathrm{E}=$ interaction between $\mathrm{CP}$ concentration and quadratic effect of DCAD.

${ }^{3} \mathrm{NS}=P>0.10$.

both $\left[\mathrm{H}^{+}\right]$and $\mathrm{pH}$; because of the asymmetric standard error of $\mathrm{pH}$ resulted from transformation, the larger number was presented as the standard error of $\mathrm{pH}$ (Murphy, 1982).

Data were analyzed with the GLM procedure (SAS Institute, 2001) according to the model for a Latin square design:

$$
\mathrm{Y}_{\mathrm{ijk}}=\mu+\mathrm{C}_{\mathrm{i}}+\mathrm{P}_{\mathrm{j}}+\mathrm{T}_{\mathrm{k}}+\mathrm{e}_{\mathrm{ijk}}
$$

where $\mu=$ overall mean; $\mathrm{C}_{\mathrm{i}}=$ effect of cow $\mathrm{i}(\mathrm{i}=1,2,3$, $4,5,6) ; \mathrm{P}_{\mathrm{j}}=$ effect of period $\mathrm{j}(\mathrm{j}=1,2,3,4,5,6) ; \mathrm{T}_{\mathrm{k}}=$ effect of treatment $\mathrm{k}(\mathrm{k}=1,2,3,4,5,6)$; and $\mathrm{e}_{\mathrm{ijk}}=$ error term.

Significance was defined as $P \leq 0.05$; whereas $0.05<$ $P \leq 0.10$ was considered to indicate a trend toward a significant effect. Contrasts were constructed, and the single degree-of-freedom orthogonal comparisons were dietary CP (16 vs. 19\%); linear effect of DCAD; quadratic effect of DCAD; the interaction of linear effect of $\mathrm{DCAD}$ and dietary CP; and the interaction of quadratic effect of DCAD and dietary CP.

\section{RESULTS AND DISCUSSION}

\section{$D M I$ and $B W$}

Table 2 presents DMI and BW for cows fed the 6 treatment diets. Dry matter intake increased linearly with increasing DCAD (Table 2, Figure 1). This is similar to earlier research that demonstrated a positive relationship between DCAD and DMI (Tucker et al.,
1991; West et al., 1991; Delaquis and Block, 1995b). Hu and Murphy (2004) found a quadratic effect of DCAD on DMI based on analysis of 12 studies; DMI peaked at a $\operatorname{DCAD}(\mathrm{Na}+\mathrm{K}-\mathrm{Cl})$ of $40 \mathrm{mEq} / 100 \mathrm{~g}$ of DM. A quadratic effect of DCAD on DMI was not identified and was unlikely to be demonstrated based on the distribution of actual DCAD in the present study; therefore, a DCAD to maximize DMI could not be estimated. This difference might be related to the different metabolic characteristics of cows and to the different dietary compositions. Those in the present experiment were in early lactation and had mean milk yields of $>35.0 \mathrm{~kg} / \mathrm{d}$; this was much higher than the $23.0 \mathrm{~kg} / \mathrm{d}$ in data analyzed by Hu and Murphy (2004). Moreover, moderate to high

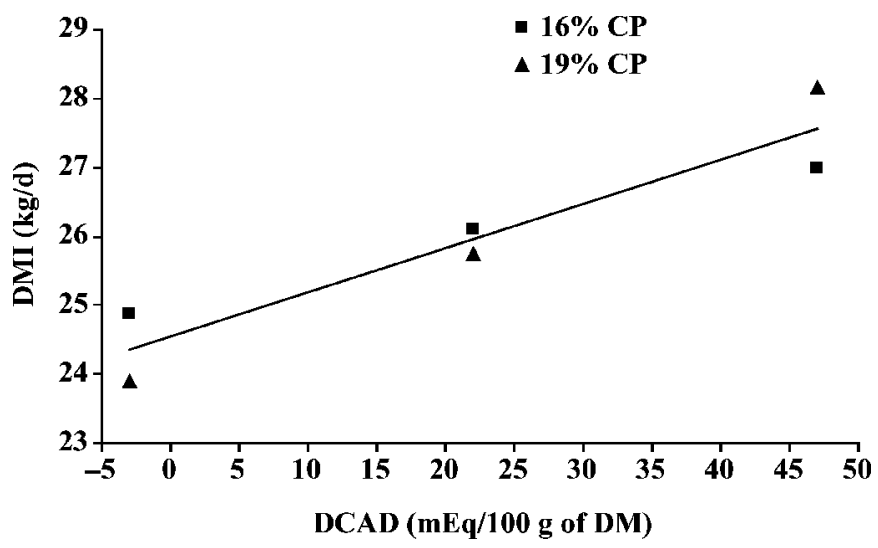

Figure 1. The effect of DCAD on DMI; DMI $(\mathrm{kg} / \mathrm{d})=0.0639 \times$ $\mathrm{DCAD}(\mathrm{mEq} / 100 \mathrm{~g}$ of $\mathrm{DM})+24.554 ; \mathrm{R}^{2}=0.89$. 
forage were included in the diets of Hu and Murphy (2004) compared with the diets reported here (Table 1). Further research is needed to determine optimal DCAD for high-producing cows in early lactation with different dietary fiber concentrations.

The mechanism for the relationship between DMI and DCAD was not clear. Increased DMI with DCAD in the present experiment was associated with acidbase status, indicated by increased blood $\mathrm{pH}$ and $\mathrm{HCO}_{3}{ }^{-}$. Consistently, the feed intake of steers was reduced with acidosis, a response linked to decreased blood $\mathrm{HCO}_{3}{ }^{-}$(Huber, 1976). Palatability of the anionic salt source or systemic acidosis resulting from an increase of dietary anions, especially when DCAD was manipulated to be negative, might reduce feed intake (Hu and Murphy, 2004). Oetzel (2002) speculated that the reduction in feed intake for nonlactating dairy cows is likely caused by the acidogenic response to anion supplementation, rather than inherent poor palatability of supplemental acidogenic salts. This was supported by the observation that the more acidogenic mixtures caused the greatest feed intake depression of nonlactating dairy cows in a comparison among several different anion sources (Vagnoni and Oetzel, 1998).

No difference was found in DMI for diets containing 16 vs. $19 \%$ CP. Neither DCAD nor dietary CP concentration affected BW.

\section{Milk Production and Composition}

Milk yield did not differ among treatments. However, milk fat percentage increased linearly $(P=0.02)$ with DCAD, and thus milk fat yield increased linearly $(P=$ 0.01 ). Because of increased milk fat percentage, $4 \%$ FCM yield increased linearly with increasing DCAD $(P=0.01)$. These results are consistent with those of others (West et al., 1991; Roche et al., 2005) that have demonstrated a positive relationship between DCAD and milk fat concentration and fat yield. The function of DCAD and buffers is confounded because DCAD increases with addition of buffers such as $\mathrm{NaHCO}_{3}$. Numerous studies have shown that addition of dietary buffers such as $\mathrm{NaHCO}_{3}$ increases milk fat percentage, especially when depressed milk fat occurred. The effect of $\mathrm{NaHCO}_{3}$ on milk fat production is probably mediated via the rumen. Ruminal $\mathrm{pH}$ increased in cows fed corn silage with addition of $\mathrm{NaHCO}_{3}$ by 0.13 units, compared with diets without addition of $\mathrm{NaHCO}_{3}$ (Hu and Murphy, 2005). Milk fat percentage is positively related to ruminal $\mathrm{pH}$ (Allen, 1997). In the experiment reported here, corn silage was fed to dairy cows as forage fiber source, and dietary ADF and NDF average contents were as low, at about 15.1 and $26.6 \%$, respectively (Table 1). The ruminal $\mathrm{pH}$ and fermentation patterns were not determined; however, it would be anticipated that the fermentation pattern and the pathways of rumen biohydrogenation might have been affected by DCAD, possibly via altering ruminal $\mathrm{pH}$. It was shown that DCAD is closely related to systemic acid-base status of the cows (Table 3). Therefore, improved milk fat percentage resulting from DCAD is likely via modification of the ruminal environment or systemic acid-base regulation. Roche et al. (2005) attributed increased milk fat resulting from increasing $\mathrm{DCAD}$ to an increase in substrate for milk fat synthesis, via either greater DMI, resulting in increased uptake of preformed fatty acids from blood; or elevated ruminal $\mathrm{pH}$ favoring acetate and butyrate production, resulting in increased de novo synthesis of fatty acids within mammary epithelial cells. On examination of DMI in the present experiment, it is evident that increasing DCAD from -3 to $+47 \mathrm{mEq} / 100 \mathrm{~g}$ of $\mathrm{DM}$ raised DMI by $13 \%$, with milk fat percentage and fat yield increasing by 20 and $21 \%$, respectively.

There was a positive linear effect of DCAD on milk true protein percentage $(P<0.01$, Table 2$)$, and milk true protein yield tended to increase linearly $(P=0.07)$ with DCAD. Milk lactose $(P=0.03)$ and $\operatorname{SNF}(P<0.01)$ concentrations increased linearly with DCAD but there were no differences in milk lactose and SNF production.

Milk urea $\mathrm{N}$ decreased linearly with increasing $\operatorname{DCAD}(P=0.02)$; this effect is consistent with the linear increase in milk true protein percentage, and the trend to increased milk true protein yield linearly as DCAD increased. As expected, MUN increased $(P<0.01)$ in cows fed diets with 19\% CP compared with those with $16 \%$ CP. Other than MUN, milk yield and composition were unaffected by dietary CP concentration. Somatic cell count was not affected by dietary treatments.

\section{Milk pH and Jugular Venous Blood Acid-Base Status}

Milk $\left[\mathrm{H}^{+}\right]$tended to increase with DCAD $(P=0.10)$, but total daily secretion of $\mathrm{H}^{+}$in milk was not affected by DCAD (Table 3). This contrasts with Delaquis and Block (1995b), who observed elevated total daily secretion of $\mathrm{H}^{+}$in the milk of early lactating cows when consuming DCAD of 25.8 vs. $5.6 \mathrm{mEq} / 100 \mathrm{~g}$ of DM. In addition, milk $\left[\mathrm{H}^{+}\right]$and total secretion of $\mathrm{H}^{+}$in milk did not differ between 16 and 19\% CP treatments. Jugular venous blood $\mathrm{pH}$ increased linearly with increasing DCAD $(P=0.01)$. Jugular venous blood $\mathrm{pH}$ was lowest in cows receiving $\mathrm{DCAD}$ of $-3 \mathrm{mEq} / 100 \mathrm{~g}$ of $\mathrm{DM}$ and highest in cows receiving DCAD of $47 \mathrm{mEq} / 100 \mathrm{~g}$ of $\mathrm{DM}$, but still within the normal range of 7.27 to 7.50 (Swenson, 1993). The result was not surprising because maintenance of $\mathrm{pH}$ is a principal goal of homeostasis. 
Table 3. Least squares means for milk $\mathrm{pH}$, jugular venous blood acid-base measures and mineral concentrations in experimental diets combining 3 levels of DCAD with 2 levels of $\mathrm{CP}$

\begin{tabular}{|c|c|c|c|c|c|c|c|c|c|c|c|c|}
\hline \multirow[b]{2}{*}{ Variable } & \multicolumn{2}{|c|}{$\mathrm{DCAD}^{1}=-3$} & \multicolumn{2}{|c|}{$\mathrm{DCAD}=22$} & \multicolumn{2}{|c|}{$\mathrm{DCAD}=47$} & \multirow[b]{2}{*}{ SE } & \multicolumn{5}{|c|}{ Orthogonal contrast $^{2}$} \\
\hline & $16 \% \mathrm{CP}$ & $19 \% \mathrm{CP}$ & $16 \% \mathrm{CP}$ & $19 \% \mathrm{CP}$ & $16 \% \mathrm{CP}$ & $19 \% \mathrm{CP}$ & & A & B & $\mathrm{C}$ & $\mathrm{D}$ & $\mathrm{E}$ \\
\hline \multicolumn{13}{|l|}{ Milk } \\
\hline $\begin{array}{l}\mathrm{H}^{+} \text {concentration, } \mathrm{n} M \\
\mathrm{pH}\end{array}$ & $\begin{array}{l}199 \\
6.70\end{array}$ & $\begin{array}{l}203 \\
\quad 6.69\end{array}$ & $\begin{array}{l}191 \\
6.72\end{array}$ & $\begin{array}{l}195 \\
6.71\end{array}$ & $\begin{array}{l}189 \\
6.72\end{array}$ & $\begin{array}{l}194 \\
6.71\end{array}$ & $\begin{array}{c}12.4 \\
0.03\end{array}$ & $\mathrm{NS}^{3}$ & 0.10 & NS & NS & NS \\
\hline $\begin{array}{l}\mathrm{H}^{+} \text {secretion, } \mathrm{n} M / \mathrm{d} \\
\text { Blood }\end{array}$ & 6,885 & 7,360 & 6,898 & 6,956 & 6,769 & 7,073 & 707 & NS & NS & NS & NS & NS \\
\hline $\begin{array}{l}\mathrm{H}^{+} \text {concentration, } \mathrm{n} M \\
\mathrm{pH}\end{array}$ & $\begin{array}{l}42.5 \\
7.371\end{array}$ & $\begin{array}{l}43.2 \\
7.365\end{array}$ & $\begin{array}{l}42.3 \\
7.373\end{array}$ & $\begin{array}{l}40.6 \\
7.392\end{array}$ & $\begin{array}{l}41.1 \\
7.386\end{array}$ & $\begin{array}{l}39.5 \\
7.403\end{array}$ & $\begin{array}{l}2.1 \\
0.022\end{array}$ & NS & 0.01 & NS & NS & NS \\
\hline $\mathrm{pCO}_{2}, \mathrm{mmHg}$ & 45.7 & 46.9 & 49.1 & 46.8 & 47.2 & 46.8 & 2.9 & NS & NS & NS & NS & NS \\
\hline $\mathrm{pO}_{2}, \mathrm{mmHg}$ & 28.9 & 28.5 & 29.0 & 27.7 & 28.2 & 28.7 & 1.8 & NS & NS & NS & NS & NS \\
\hline $\mathrm{HCO}_{3}^{-}, \mathrm{mEq} / \mathrm{L}$ & 25.5 & 25.9 & 27.5 & 27.5 & 28.4 & 28.2 & 1.5 & NS & $<0.01$ & NS & NS & NS \\
\hline Base excess, $\mathrm{m} M$ & 0.5 & 0.6 & 2.1 & 2.3 & 3.1 & 3.3 & 1.5 & NS & $<0.01$ & NS & NS & NS \\
\hline $\mathrm{Na}^{+}, \mathrm{mEq} / \mathrm{L}$ & 132.3 & 133.8 & 134.4 & 133.1 & 132.2 & 132.5 & 1.2 & NS & NS & 0.06 & NS & 0.05 \\
\hline $\mathrm{K}^{+}, \mathrm{mEq} / \mathrm{L}$ & 4.11 & 4.10 & 3.95 & 3.85 & 4.11 & 4.22 & 0.21 & NS & NS & 0.02 & NS & NS \\
\hline $\mathrm{Cl}^{-}, \mathrm{mEq} / \mathrm{L}$ & 100.3 & 99.8 & 99.5 & 98.4 & 97.1 & 97.8 & 0.76 & NS & $<0.01$ & NS & NS & 0.08 \\
\hline $\mathrm{Ca}^{2+}, \mathrm{mg} / \mathrm{dL}$ & 4.75 & 4.73 & 4.74 & 4.67 & 4.77 & 4.58 & 0.26 & NS & NS & NS & NS & NS \\
\hline $\mathrm{BCAD},{ }^{4} \mathrm{mEq} / \mathrm{L}$ & 36.0 & 38.1 & 38.3 & 38.6 & 39.0 & 38.9 & 1.1 & NS & 0.01 & NS & 0.06 & NS \\
\hline Anion gap, ${ }^{5} \mathrm{mEq} / \mathrm{L}$ & 11.2 & 12.1 & 11.6 & 11.4 & 11.4 & 11.4 & 0.8 & NS & NS & NS & NS & NS \\
\hline
\end{tabular}

${ }^{1} \mathrm{DCAD}$ in milliequivalents of $(\mathrm{Na}+\mathrm{K}-\mathrm{Cl}-\mathrm{S}) / 100 \mathrm{~g}$ of $\mathrm{DM}$.

${ }^{2} \mathrm{~A}=16 \% \mathrm{CP}$ vs. $19 \% \mathrm{CP} ; \mathrm{B}=$ linear effect of $\mathrm{DCAD} ; \mathrm{C}=$ quadratic effect of $\mathrm{DCAD} ; \mathrm{D}=$ interaction between $\mathrm{CP}$ concentration and linear effect of DCAD; $\mathrm{E}=$ interaction between $\mathrm{CP}$ concentration and quadratic effect of DCAD.

${ }^{3} \mathrm{NS}=P>0.10$.

${ }^{4} \mathrm{BCAD}=$ jugular venous blood cation-anion difference $(\mathrm{Na}+\mathrm{K}-\mathrm{Cl})$.

${ }^{5}$ Anion gap $=$ jugular venous blood $\mathrm{Na}^{+}+\mathrm{K}^{+}-\mathrm{Cl}^{-}-\mathrm{HCO}_{3}^{-}$.

Jugular venous blood $\mathrm{HCO}_{3}{ }^{-}$reflected changes in jugular venous blood $\mathrm{pH}(P<0.01)$ with DCAD treatment. This is in agreement with most previous work in which blood $\mathrm{pH}$ and $\mathrm{HCO}_{3}{ }^{-}$increased with DCAD ( $\mathrm{Hu}$ and Murphy, 2004; Roche et al., 2005).

Dairy cows might use different approaches to regulate changed blood $\mathrm{HCO}_{3}{ }^{-}$caused by diet treatment via either respiration or metabolic compensation, or a combination of both. In the present experiment, neither jugular venous blood $\mathrm{pCO}_{2}$ nor $\mathrm{pO}_{2}$ was affected by DCAD. Others have also reported that there was no effect of DCAD on blood $\mathrm{pCO}_{2}$ (Tucker et al., 1991; Vagnoni and Oetzel, 1998; Roche et al., 2003), suggesting there was no respiratory compensation for dietrelated changes in blood $\mathrm{HCO}_{3}{ }^{-}$. However, these results appear to contradict that of a meta-analysis by $\mathrm{Hu}$ and Murphy (2004), who demonstrated a significant effect of DCAD on blood $\mathrm{pCO}_{2}$ of lactating dairy cows. Similarly, another meta-analysis with nonlactating dairy cow data also indicated that blood $\mathrm{pCO}_{2}$ was significantly altered by DCAD (Charbonneau et al., 2006). It should be noted that the effect of DCAD on blood $\mathrm{pCO}_{2}$ might not be evident in the individual study (Tucker et al., 1991; Vagnoni and Oetzel, 1998; Roche et al., 2003), but was shown clearly in the meta-analysis ( $\mathrm{Hu}$ and Murphy, 2004; Charbonneau et al., 2006).

Base excess is an empirical expression that approximates the amount of acid or base needed to titrate $1 \mathrm{~L}$ of blood with a $\mathrm{pCO}_{2}$ of $40 \mathrm{mmHg}$, a total hemoglobin of $15 \mathrm{~g} / \mathrm{dL}$, and a temperature of $37^{\circ} \mathrm{C}$ to a normal $\mathrm{pH}$ of 7.40 (Constable, 1999). By definition, the normal base excess value for humans is zero. Because blood protein and phosphate concentrations and blood buffering capacity vary with species, calculated base excess values for domestic animals differ from those of humans (Constable, 1999, 2000). It is unclear what normal base excess values of lactating dairy cows are; however, it was obvious in the present experiment that jugular venous blood base excess increased linearly $(P<0.01)$ with increasing DCAD, implying that the diets were less acidogenic with increasing DCAD.

Jugular venous blood $\mathrm{pH}, \mathrm{pCO}_{2}, \mathrm{pO}_{2}, \mathrm{HCO}_{3}^{-}$, and base excess did not differ between cows fed $16 \% \mathrm{CP}$ and those fed $19 \% \mathrm{CP}$.

\section{Blood Minerals}

Coccygeal venous plasma concentrations of $\mathrm{Na}^{+}$and $\mathrm{K}^{+}$were not altered by DCAD even though dietary contents of $\mathrm{Na}$ and $\mathrm{K}$ were much higher for cows receiving diet with a DCAD of $47 \mathrm{mEq} / 100 \mathrm{~g}$ of $\mathrm{DM}$, compared with cows with a DCAD of -3 or $22 \mathrm{mEq} / 100 \mathrm{~g}$ of DM. This is in agreement with the observations of Tucker et al. $(1988,1991)$, who found that $\mathrm{Na}$ and K concentrations in the serum or plasma were not influenced by DCAD in lactating cows. Roche et al. (2005), however, observed a quadratic increase in blood serum Na concentration and a linear decrease in blood serum $\mathrm{K}$ con- 
Table 4. Least squares means for urea N, creatinine, and mineral concentrations in coccygeal venous plasma in experimental diets combining 3 levels of DCAD with 2 levels of CP

\begin{tabular}{|c|c|c|c|c|c|c|c|c|c|c|c|c|}
\hline Variable & \multicolumn{2}{|c|}{$\mathrm{DCAD}^{1}=-3$} & \multicolumn{2}{|c|}{$\mathrm{DCAD}=22$} & \multicolumn{2}{|c|}{$\mathrm{DCAD}=47$} & SE & \multicolumn{5}{|c|}{ Orthogonal contrast ${ }^{2}$} \\
\hline Urea $\mathrm{N}, \mathrm{mg} / \mathrm{dL}$ & 18.3 & 23.4 & 17.2 & 26.0 & 16.5 & 23.6 & 2.0 & $<0.01$ & $\mathrm{NS}^{3}$ & $\mathrm{NS}$ & NS & 0.06 \\
\hline Creatinine, $\mathrm{mg} / \mathrm{dL}$ & 0.76 & 0.65 & 0.65 & 0.65 & 0.67 & 0.55 & 0.06 & $<0.01$ & $<0.01$ & NS & NS & 0.02 \\
\hline $\mathrm{Na}^{+}, \mathrm{mEq} / \mathrm{L}$ & 138.9 & 137.7 & 138.0 & 137.2 & 137.3 & 136.7 & 2.5 & NS & NS & $\mathrm{NS}$ & NS & NS \\
\hline $\mathrm{K}^{+}, \mathrm{mEq} / \mathrm{L}$ & 4.38 & 4.40 & 4.52 & 4.15 & 4.33 & 4.38 & 0.23 & NS & NS & NS & NS & 0.03 \\
\hline $\mathrm{Cl}^{-}, \mathrm{mEq} / \mathrm{L}$ & 102.0 & 99.5 & 98.8 & 96.8 & 97.8 & 97.3 & 1.8 & 0.02 & $<0.01$ & 0.06 & NS & NS \\
\hline
\end{tabular}

${ }^{1} \mathrm{DCAD}$ in milliequivalents of $(\mathrm{Na}+\mathrm{K}-\mathrm{Cl}-\mathrm{S}) / 100 \mathrm{~g}$ of $\mathrm{DM}$.

${ }^{2} \mathrm{~A}=16 \% \mathrm{CP}$ vs. $19 \% \mathrm{CP} ; \mathrm{B}=$ linear effect of $\mathrm{DCAD} ; \mathrm{C}=$ quadratic effect of $\mathrm{DCAD} ; \mathrm{D}=$ interaction between $\mathrm{CP}$ concentration and linear effect of DCAD; $\mathrm{E}=$ interaction between $\mathrm{CP}$ concentration and quadratic effect of DCAD.

${ }^{3} \mathrm{NS}=P>0.10$.

${ }^{4} \mathrm{PCAD}=$ coccygeal venous plasma cation-anion difference $(\mathrm{Na}+\mathrm{K}-\mathrm{Cl})$.

centration in early lactating cows as DCAD increased. Interestingly, a trend for a quadratic effect of DCAD $(P=0.06)$ on jugular venous blood $\mathrm{Na}^{+}$concentrations and a quadratic effect of DCAD on jugular venous blood $\mathrm{K}^{+}(P=0.02)$ concentrations were found in the present study.

Coccygeal venous plasma $\mathrm{Cl}^{-}$, as jugular venous blood $\mathrm{Cl}^{-}$, decreased linearly with increasing DCAD $(P<0.01)$; the high plasma $\mathrm{Cl}^{-}$concentration was noted in the low DCAD treatment of $-3 \mathrm{mEq} / 100 \mathrm{~g}$ of DM. Some other studies (Escobosa et al., 1984; West et al., 1991) also reported increases in plasma $\mathrm{Cl}$ concentration in cows fed diets with high $\mathrm{Cl}$ content. Therefore, a high coccygeal venous plasma $\mathrm{Cl}^{-}$concentration might be associated with high $\mathrm{Cl}$ content of the DCAD of $-3 \mathrm{mEq} / 100$ $\mathrm{g}$ of DM diet. However, Patience and Chaplin (1997) compared different DCAD diets with 2 similar dietary $\mathrm{Cl}$ contents in swine and found that serum $\mathrm{Cl}$ concentration was significantly lower for the diet with lower $\mathrm{DCAD}$, indicating that serum $\mathrm{Cl}$ might be affected by DCAD components other than $\mathrm{Cl}$.

Jugular venous blood cation-anion difference [BCAD, expressed as $\mathrm{mEq}(\mathrm{Na}+\mathrm{K}-\mathrm{Cl}) / \mathrm{L}]$ increased linearly with increasing $\mathrm{DCAD}(P=0.01)$. As BCAD increases, more $\mathrm{HCO}_{3}{ }^{-}$should be generated and released to maintain electrical neutrality. This was supported by the apparent linear relationship between jugular venous blood $\mathrm{HCO}_{3}{ }^{-}$and BCAD (Table 4, Figure 2). Therefore, DCAD probably affects blood $\mathrm{pH}$ via altering blood $\mathrm{HCO}_{3}{ }^{-}$concentration.

Jugular venous blood $\mathrm{Ca}^{2+}$ was not altered by DCAD, a result consistent with that of Hu and Murphy (2004). Prepartum diets supplemented with acidogenic salts (i.e., low DCAD) increase plasma Ca concentration for cows at parturition (Oetzel et al., 1988; Goff et al., 1991; Charbonneau et al., 2006).
Coccygeal venous plasma $\mathrm{Cl}^{-}$concentration was higher (99.5 vs. $97.9 \mathrm{mEq} / \mathrm{L})$ in diets with 16 vs. $19 \%$ $\mathrm{CP}(P=0.02)$. Interactions between quadratic effect of DCAD and CP concentration on jugular venous blood $\mathrm{Na}^{+}$concentration $(P=0.05)$ and coccygeal venous plasma $\mathrm{K}^{+}$concentration $(P=0.03)$ were also observed. No explanation for these results is apparent.

In most previous DCAD research, blood mineral contents were determined from either plasma or serum (Hu and Murphy, 2004). By contrast, minerals (especially $\mathrm{Na}, \mathrm{K}$, and $\mathrm{Cl}$ ) in both whole blood collected from jugular vein and blood plasma collected from the coccygeal vein were determined in the present experiment via ion-selective electrode using the blood gas analyzer (Rapidlab 850 system, Bayer Diagnostics) and the Hitachi 917 analyzer (Roche), respectively. Some differences of mineral contents in 2 blood samples have been observed and consequently, the statistical evaluation

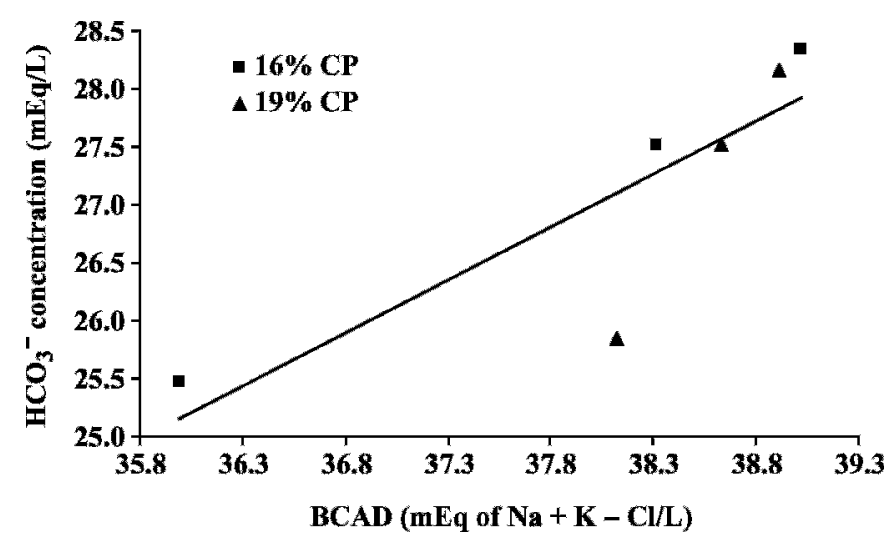

Figure 2. Relationship between jugular venous blood cation-anion difference $\left(\mathrm{BCAD} ; \mathrm{Na}+\mathrm{K}-\mathrm{Cl}\right.$ ) and $\mathrm{HCO}_{3}{ }^{-}$concentration; $\mathrm{HCO}_{3}{ }^{-}$ $(\mathrm{mEq} / \mathrm{L})=0.9145 \times \mathrm{BCAD}(\mathrm{mEq}$ of $\mathrm{Na}+\mathrm{K}-\mathrm{Cl} / \mathrm{L})-7.7611 ; \mathrm{R}^{2}=0.72$. 
of effect of DCAD and dietary protein on those minerals might not be consistent (Tables 3 and 4). Caution should be taken to interpret those mineral results between 2 blood samples, because real differences could result from factors such as different sampling sites (i.e., jugular vs. coccygeal vein) in lactating cows (P. D. Constable, unpublished data).

\section{Coccygeal Venous Plasma Urea $N$ and $A A$}

The DCAD did not affect coccygeal venous plasma urea $\mathrm{N}$ concentration, which is contrary to results of Roche et al. (2005), who found that blood urea concentration of cows in early lactation increased linearly with increasing DCAD. There was a difference of coccygeal venous plasma urea $\mathrm{N}(P<0.01)$, as expected, between 16 and $19 \% \mathrm{CP}(17.3$ vs. $24.3 \mathrm{mg} / \mathrm{dL})$. The trend $(P=$ 0.06 ) of an interaction between the quadratic effect of DCAD and CP concentration on coccygeal venous plasma urea $\mathrm{N}$ concentration suggested that plasma urea $\mathrm{N}$ responded differently to DCAD at 16 or $19 \% \mathrm{CP}$ (Table 4).

Effect of DCAD on the coccygeal venous plasma urea $\mathrm{N}$ concentration was not the same as that of DCAD on MUN concentration. The urea $\mathrm{N}$ results should be cautiously interpreted. Plasma urea $\mathrm{N}$ concentration was expected to be equivalent to MUN concentration because urea diffuses freely from blood to milk; however, the coccygeal venous plasma urea $\mathrm{N}$ concentration was higher than MUN concentration in this experiment (Tables 2 and 4). The difference could result from different time of sampling (Gustafsson and Palmquist, 1993), and from different test procedures that were used to measure urea $\mathrm{N}$ concentrations in plasma and milk. Nonetheless, a strong relationship between the plasma urea $\mathrm{N}$ concentration and the MUN concentration was found (data not shown), which is consistent with the results of Broderick and Clayton (1997).

Coccygeal venous plasma concentrations of AA are presented in Table 5. Valine $(P=0.03)$ increased, and Ile $(P=0.10)$ and total branched-chain AA (BCAA, $P=$ 0.06 ) tended to increase linearly with increasing DCAD. Also, with increasing DCAD, Arg $(P=0.02)$ and Thr $(P=0.03)$ increased, and His $(P=0.06)$ tended to increase quadratically.

Higher coccygeal venous plasma concentrations of His ( 59 vs. $54 \mu M, P=0.03$ ) and Val ( 305 vs. $272 \mu M$, $P=0.04$ ) were observed for cows fed 19 vs. $16 \% \mathrm{CP}$. Also, the ratios of essential AA (EAA) to nonessential AA (NEAA, 0.888 vs. 0.778), and EAA to total AA (TAA, 0.467 vs. 0.432 ) increased for cows fed 19 vs. $16 \%$ CP. These results reflected that more ruminal undegraded protein might pass to the small intestine when the higher percentage of dietary protein was fed.
Protein flowing to the small intestine for digestion and absorption depends on amounts of dietary protein escaping ruminal degradation, microbial protein synthesis, and the abomasal emptying rate. The blood plasma BCAA serve as indicators of AA absorption from the small intestine in dairy cows, because they are, relative to other AA, less degraded by the liver (Lobley, 1992; Dhiman and Satter, 1997). In the present experiment, coccygeal venous plasma concentrations of Val, Ile, and total BCAA (Val + Leu + Ile), ratios of EAA to NEAA and EAA to TAA increased with increasing DCAD; thus, more protein probably reached the small intestine as DCAD increased. Because the majority of protein supplied to the small intestine of ruminants is provided by microbial protein synthesized in the rumen (Bach et al., 2005), increased protein as DCAD increased probably results from increased microbial protein synthesis in the rumen. This interpretation was supported by a study of buffer effects. Mees et al. (1985) observed increased bacterial $\mathrm{N}$ flow at the duodenum and increased efficiency of bacterial protein synthesis in sheep with supplementation of $\mathrm{NaHCO}_{3}$. In addition, more undegraded dietary protein might also flow to the small intestine as DMI increased linearly with DCAD.

An interaction for the ratio of EAA to NEAA $(P=$ 0.03 ) and a trend for an interaction for the ratio of EAA to TAA $(P=0.06)$, between the quadratic effect of DCAD and $\mathrm{CP}$ concentration were observed (Table 5). When DCAD increased from 22 to $47 \mathrm{mEq} / 100 \mathrm{~g}$ of DM, similar ratios of EAA to NEAA were reached (0.870 vs. 0.895$)$ for cows fed 16 vs. $19 \% \mathrm{CP}$, indicating improved efficiency of $\mathrm{N}$ utilization for cows fed DCAD of $47 \mathrm{vs.} 22$ $\mathrm{mEq} / 100 \mathrm{~g}$ of DM. Trenkle (1979) hypothesized that similar gains could be obtained for young calves or lambs fed buffered diets with less CP, because of improved ruminal protein synthesis with addition of buffer.

A role for Gln is accepted in the regulation of acidbase balance (Guder et al., 1987; Haussinger, 1990). During acidosis, a switch from urea production to Gln synthesis in the liver was found in rodents (Welbourne et al., 1986) but not sheep (Lobley et al., 2001). Uptake of Gln by the kidneys increases during periods of acidosis; therefore, a lower plasma Gln concentration would be expected because of elevated Gln demand. In the present experiment, dietary treatments did not affect coccygeal venous plasma Gln concentration. This might have resulted from concerted regulation of gut and renal glutaminase, hepatic Gln synthesis, and urea synthesis. Also, a linear decrease was observed in coccygeal venous plasma Glu concentration with increasing DCAD. Based on available data, it is difficult to speculate on potential associations of acid-base balance with the couplet of Gln-Glu. 
Table 5. Least squares mean concentrations of AA in coccygeal venous plasma ( $\mu \mathrm{mol} / \mathrm{L})$ in experimental diets combining 3 levels of DCAD with 2 levels of $\mathrm{CP}$

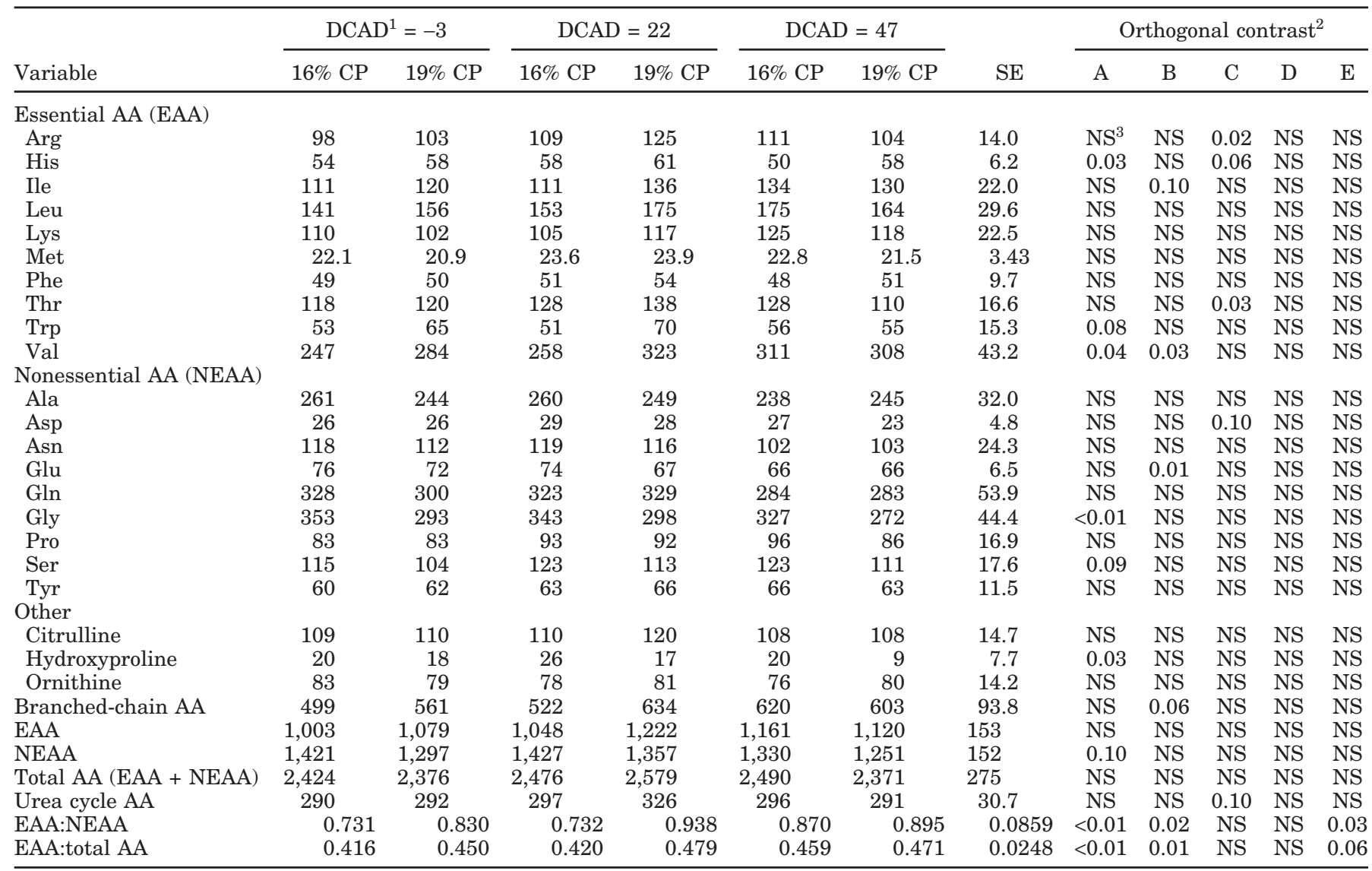

${ }^{1} \mathrm{DCAD}$ in milliequivalents of $(\mathrm{Na}+\mathrm{K}-\mathrm{Cl}-\mathrm{S}) / 100 \mathrm{~g}$ of DM.

${ }^{2} \mathrm{~A}=16 \% \mathrm{CP}$ vs. $19 \% \mathrm{CP} ; \mathrm{B}=$ linear effect of $\mathrm{DCAD} ; \mathrm{C}=$ quadratic effect of DCAD; $\mathrm{D}=$ interaction between $\mathrm{CP}$ concentration and linear effect of DCAD; $\mathrm{E}=$ interaction between $\mathrm{CP}$ concentration and quadratic effect of DCAD.

${ }^{3} \mathrm{NS}=P>0.10$.

\section{Urine $\mathrm{pH}, \mathrm{TA}$, and Minerals}

Creatinine is a waste product formed in muscle from creatine phosphate, which is excreted at a constant rate for a given lean body mass (De Groot and Aafjes, 1960; Albin and Clanton, 1966); some researchers have confirmed this finding in dry cows (Vagnoni and Oetzel, 1998; Asai et al., 2005). Changes in urinary creatinine concentrations thus indicate changes in urine concentration. Total urine output was not measured for cows in the present study; therefore, creatinine concentration in the urine was used as an index to estimate clearance of metabolites and minerals, even though coccygeal venous plasma creatinine concentration changed with DCAD and dietary CP (Table 4).

Urinary creatinine concentration decreased linearly as DCAD increased $(P<0.01$, Table 6$)$. Urine $\left[\mathrm{H}^{+}\right]$also decreased linearly with increasing DCAD $(P<0.01$, Table 6), more than 10 -fold ( $\mathrm{pH}$ changed from 6.99 to 8.01 ) by increasing DCAD from -3 to $22 \mathrm{mEq} / 100 \mathrm{~g}$ of
DM. This was similar to results of Charbonneau et al. (2006). In contrast, a relatively small decrease in urine $\left[\mathrm{H}^{+}\right]$( $\mathrm{pH}$ increased from 8.01 to 8.23) occurred as DCAD increased from 22 to $47 \mathrm{mEq} / 100 \mathrm{~g}$ of $\mathrm{DM}$.

Urine $\mathrm{pH}$ proved to be a very sensitive and practical means of assessing the degree of acidification following acidogenic salts supplementation of dry cows (Vagnoni and Oetzel, 1998; Charbonneau et al., 2006). Our results suggested the same was true for cows in early lactation when DCAD was manipulated to $-3 \mathrm{mEq} / 100$ $\mathrm{g}$ of DM by supplementing anionic salt. In contrast, changing DCAD from 22 to $47 \mathrm{mEq} / 100 \mathrm{~g}$ of DM had a relatively small effect on urine $\mathrm{pH}$. Increased urine $\mathrm{pH}$ could be attributed to increased dietary alkalinity as DCAD increased from 22 to $47 \mathrm{mEq} / 100 \mathrm{~g}$ of DM. However, urine volume apparently increased as DCAD increased. Also, urine volume might increase with increasing DMI (Murphy, 1992); consequently, dilution raised urine $\mathrm{pH}$. Moreover, ruminants are considered 
Table 6. Least squares means for urine $\mathrm{pH}$ and urine component concentrations in experimental diets combining 3 levels of DCAD with 2 levels of CP

\begin{tabular}{|c|c|c|c|c|c|c|c|c|c|c|c|c|}
\hline \multirow[b]{2}{*}{ Variable } & \multicolumn{2}{|c|}{$\mathrm{DCAD}^{1}=-3$} & \multicolumn{2}{|c|}{$\mathrm{DCAD}=22$} & \multicolumn{2}{|c|}{$\mathrm{DCAD}=47$} & \multirow[b]{2}{*}{$\mathrm{SE}$} & \multicolumn{5}{|c|}{ Orthogonal contrast $^{2}$} \\
\hline & $16 \% \mathrm{CP}$ & $19 \% \mathrm{CP}$ & $16 \% \mathrm{CP}$ & $19 \% \mathrm{CP}$ & $16 \% \mathrm{CP}$ & $19 \% \mathrm{CP}$ & & A & $\mathrm{B}$ & $\mathrm{C}$ & $\mathrm{D}$ & $\mathrm{E}$ \\
\hline $\begin{array}{l}\mathrm{H}^{+} \text {concentration, } \mathrm{n} M \\
\mathrm{pH}\end{array}$ & $\begin{array}{l}90.3 \\
7.04\end{array}$ & $\begin{array}{r}113.2 \\
6.95\end{array}$ & $\begin{array}{c}11.5 \\
7.94\end{array}$ & $\begin{array}{l}7.9 \\
8.10\end{array}$ & $\begin{array}{l}5.9 \\
8.23\end{array}$ & $\begin{array}{l}5.8 \\
8.24\end{array}$ & $\begin{array}{c}60.2 \\
0.43\end{array}$ & $\mathrm{NS}^{3}$ & $<0.01$ & 0.06 & NS & NS \\
\hline Creatinine, mg/dL & 65 & 60 & 56 & 48 & 40 & 34 & 13 & NS & $<0.01$ & NS & NS & $\mathrm{N}$ \\
\hline $\mathrm{TA},{ }^{4} \mathrm{~m} M$ & -39 & -17 & -92 & -97 & -166 & -132 & 46 & NS & $<0.01$ & NS & NS & $\mathrm{N}$ \\
\hline Ammonium, $\mathrm{m} M$ & 14.7 & 18.1 & 9.4 & 11.9 & 5.7 & 8.2 & 4.9 & NS & $<0.01$ & NS & NS & $\mathrm{N}$ \\
\hline $\mathrm{NAE},{ }^{5} \mathrm{~m} M$ & -24.3 & 0.7 & -82.7 & -85.1 & -160.6 & -124.3 & 43.9 & NS & $<0.01$ & NS & NS & $\mathrm{N}$ \\
\hline TA:creatinine, $\mathrm{m} M: \mathrm{m} M$ & -9.2 & -8.0 & -25.2 & -27.3 & -49.7 & -46.9 & 11.5 & NS & $<0.01$ & NS & NS & $\mathrm{N}$ \\
\hline Amn & 3.11 & 3.13 & 2.13 & 2.96 & 1.61 & 2.87 & 0.95 & 0.05 & 0.05 & NS & NS & $\mathrm{N}$ \\
\hline NAE:creatinine & -6.1 & -4.9 & -23.0 & -24.4 & -48.1 & -44.1 & 11.3 & NS & $<0.01$ & NS & NS & $\mathrm{N}$ \\
\hline Urea N:creatinine, mg:mg & 12.2 & 19.1 & 12.6 & 19.9 & 13.8 & 23.1 & 2.6 & $<0.01$ & 0.02 & NS & NS & $\mathrm{N}$ \\
\hline $\mathrm{Na}^{+}$:creatinine, mg:mg & 2.85 & 1.98 & 2.35 & 3.80 & 4.03 & 4.59 & 1.27 & NS & $<0.01$ & NS & NS & 0.1 \\
\hline $\mathrm{K}^{+}$:creatinine, mg:mg & 9.63 & 9.70 & 10.60 & 11.63 & 16.55 & 18.85 & 2.41 & NS & $<0.01$ & 0.01 & NS & \\
\hline $\mathrm{Cl}^{-}: \mathrm{cre}$ & 9.36 & 7.27 & 2.59 & 2.71 & 3.18 & 4.62 & 1.84 & NS & $<0.01$ & $<0.01$ & 0.05 & \\
\hline Ca:creatinine, mg:mg & 0.31 & 0.37 & 0.03 & 0.07 & 0.05 & 0.04 & 0.14 & NS & $<0.01$ & 0.02 & NS & \\
\hline
\end{tabular}

${ }^{1} \mathrm{DCAD}$ in milliequivalents of $(\mathrm{Na}+\mathrm{K}-\mathrm{Cl}-\mathrm{S}) / 100 \mathrm{~g}$ of $\mathrm{DM}$.

${ }^{2} \mathrm{~A}=16 \% \mathrm{CP}$ vs. $19 \% \mathrm{CP} ; \mathrm{B}=$ linear effect of $\mathrm{DCAD} ; \mathrm{C}=$ quadratic effect of DCAD; $\mathrm{D}=$ interaction between $\mathrm{CP}$ concentration and linear effect of DCAD; $\mathrm{E}=$ interaction between $\mathrm{CP}$ concentration and quadratic effect of DCAD.

${ }^{3} \mathrm{NS}=P>0.10$

${ }^{4} \mathrm{TA}=$ titratable acidity, the amount of $\mathrm{NaOH}$ required to titrate $\mathrm{HCl}$ acidified and boiled urine to $\mathrm{pH}$ 7.4.

${ }^{5} \mathrm{NAE}=$ net acid excretion, measured TA plus ammonium.

to possess a tremendous base reserve (Atkinson and Camien, 1982). The normal $\mathrm{pH}$ of bovine urine, like that of all herbivores, is greater than 8 , and the urine $\mathrm{pH}$ of dairy cows fed cationic diets could be as high as 8.2 (Oetzel, 2002). Results of the present experiment indicated that cows fed DCAD of $22 \mathrm{mEq} / 100 \mathrm{~g}$ of DM or higher maintained normal urine $\mathrm{pH}$ (i.e., >8.0).

In addition to free $\mathrm{H}^{+}$excreted in the urine, most urinary $\mathrm{H}^{+}$are associated with buffers or ammonia. Measuring urinary net acid excretion might be a much more sensitive method of quantifying metabolic acid load in dairy cows than blood acid-base parameters (Erdman, 1988). Urinary TA and $\mathrm{NH}_{4}^{+}$were increased in dry cows by dietary acidogenic salts (Wang and Beede, 1992; Vagnoni and Oetzel, 1998). Little information is available for lactating cows. Based on our data, excretion of both TA as TA:creatinine $(P<0.01)$ and $\mathrm{NH}_{4}{ }^{+}$as $\mathrm{NH}_{4}{ }^{+}$:creatinine $(P=0.05)$ decreased linearly with increasing DCAD; consequently, NAE as NAE:creatinine $(P<0.01)$, decreased linearly with increasing DCAD. The mean NAE:creatinine of diets with DCAD of $-3,22$, and $47 \mathrm{mEq} / 100 \mathrm{~g}$ of DM were -5.5 , -23.7 , and -46.1 , respectively, clearly demonstrating that the acid-base status of the cows was affected by DCAD manipulation. Moreover, with increasing DCAD, urea $\mathrm{N}$ excretion $(P=0.02)$, as urea $\mathrm{N}$ :creatinine, linearly increased; whereas $\mathrm{NH}_{4}^{+}(P=0.05)$, as $\mathrm{NH}_{4}{ }^{+}$:creatinine, linearly decreased. An association of urea and ammonia synthesis with regulation of acidbase balance in the cow was indicated.
The DCAD was increased by $\mathrm{NaHCO}_{3}$ and $\mathrm{K}_{2} \mathrm{CO}_{3}$ addition; therefore, it was not surprising that urinary $\mathrm{Na}^{+}$excretion, as $\mathrm{Na}^{+}$:creatinine, increased linearly $(P$ $<0.01$ ), and $\mathrm{K}^{+}$excretion, as $\mathrm{K}^{+}$:creatinine, increased quadratically $(P<0.01)$ with DCAD. Similarly, DCAD was reduced by adding $\mathrm{CaCl}_{2}$, and $\mathrm{Cl}^{-}$excretion was highest in DCAD of $-3 \mathrm{mEq} / 100 \mathrm{~g}$ of DM compared with the other 2 DCAD treatments. Diets with DCAD of 22 and $47 \mathrm{mEq} / 100 \mathrm{~g}$ of $\mathrm{DM}$ had similar $\mathrm{Cl}^{-}$contents, but cows fed a higher DCAD diet had a greater rate of urinary $\mathrm{Cl}^{-}$excretion, suggesting that increased excretion of $\mathrm{Cl}^{-}$might be needed to accompany renal excretion of excess $\mathrm{Na}^{+}$or $\mathrm{K}^{+}$because of higher amounts of $\mathrm{Na}$ and $\mathrm{K}$ content in the diet with DCAD of $47 \mathrm{mEq} /$ $100 \mathrm{~g}$ of DM.

The concentration of $\mathrm{Ca}$ in urine (Ca:creatinine) decreased quadratically with DCAD $(P=0.02)$, although there were no differences in jugular venous blood $\mathrm{Ca}^{2+}$ or coccygeal venous plasma Ca concentrations. Urinary Ca excretion was highest for cows with DCAD of -3 $\mathrm{mEq} / 100 \mathrm{~g}$ of DM; whereas it was much lower at DCAD of 22 and $47 \mathrm{mEq} / 100 \mathrm{~g}$ of DM. As DCAD declined, Ca supplementation increased from $\mathrm{CaCl}_{2}$ in the present study (Table 1). The source of additional urinary $\mathrm{Ca}$ excretion when low or negative DCAD diets are fed is still debated. Increased excretion of $\mathrm{Ca}$ with low or negative DCAD may be attributed to increased intestinal absorption (Fredeen et al., 1988; Schonewille et al., 1994), increased bone resorption (Block, 1984; Goff et al., 1991), or a combination of both. 
The pattern of urinary excretion of $\mathrm{Na}^{+}, \mathrm{K}^{+}, \mathrm{Cl}^{-}$, and Ca expressed relative to creatinine (Table 6) reflected dietary mineral composition. Urinary mineral excretions were much more responsive than whole blood or plasma mineral concentrations to dietary mineral contents. Therefore, only small changes in blood or plasma mineral concentrations resulted across dietary treatments, suggesting the presence of adequate inherent homeostatic mechanisms to maintain acid-base and mineral status in dairy cows.

Urinary urea N:creatinine $(P<0.01)$ and $\mathrm{NH}_{4}{ }^{+}$:creatinine $(P=0.05)$ were higher in cows fed 19 vs. $16 \% \mathrm{CP}$; otherwise, dietary CP concentration had no significant impact on urine $\mathrm{pH}$ or other urine components. This contrasted with Wang and Beede (1992), who reported that increasing supplemental CP increased urinary $\mathrm{NH}_{4}{ }^{+}$excretion, and also decreased blood base excess and urinary titratable base of nonlactating Jersey cows. Moreover, increased protein intake by humans increased renal NAE by increasing urinary $\mathrm{NH}_{4}{ }^{+}$excretion at any given urine $\mathrm{pH}$ (Remer, 2000).

\section{CONCLUSIONS}

The DCAD affected DM intake and performance of dairy cows in early lactation. Higher jugular venous blood $\mathrm{pH}$, higher jugular venous blood $\mathrm{HCO}_{3}^{-}$concentration and base excess, and decreased net acid excretion with increasing DCAD suggested that the acidbase status of the cows was improved. Elevated coccygeal venous plasma BCAA and ratio of EAA to NEAA with increasing DCAD indicated that $\mathrm{N}$ metabolism in the rumen was affected, probably resulting in more microbial protein flowing to the small intestine. Performance and acid-base status were not affected when early lactating cows were fed 16 or $19 \%$ CP. Feeding $16 \%$ dietary CP to cows in early lactation, compared with $19 \% \mathrm{CP}$, maintained lactation performance while reducing urea $\mathrm{N}$ excretion in milk and urine.

\section{REFERENCES}

Albin, R. C., and D. C. Clanton. 1966. Factors contributing to the variation in urinary creatinine and creatinine-nitrogen ratios in beef cattle. J. Anim. Sci. 25:107-112.

Allen, M. S. 1997. Relationship between fermentation acid production in the rumen and the requirement for physically effective fiber. J. Dairy Sci. 80:1447-1462.

Asai, H., N. Hayashi, N. Takai, Y. Yoshimura, Y. Nakamura, H. Yokota, and K. Kita. 2005. Estimation of daily urinary potassium excretion using urinary creatinine as an index substance in prepartum dairy cows. Anim. Sci. J. 76:51-54.

Atkinson, D. E., and M. N. Camien. 1982. The role of urea synthesis in the removal of metabolic bicarbonate and the regulation of blood pH. Curr. Top. Cell. Regul. 21:261-303.

Bach, A., S. Calsamiglia, and M. D. Stern. 2005. Nitrogen metabolism in the rumen. J. Dairy Sci. 88(E Suppl.):E9-E21.
Block, E. 1984. Manipulating dietary anions and cations for prepartum dairy cows to reduce incidence of milk fever. J. Dairy Sci. 67:2939-2948.

Broderick, G. A., and M. K. Clayton. 1997. A statistical evaluation of animal and nutritional factors influencing concentrations of milk urea nitrogen. J. Dairy Sci. 80:2964-2971.

Chan, J. C. M. 1972. The rapid determination of urinary titratable acid and ammonium and evaluation of freezing as a method of preservation. Clin. Biochem. 5:94-98.

Charbonneau, E., D. Pellerin, and G. R. Oetzel. 2006. Impact of lowering dietary cation-anion difference in nonlactating dairy cows: a meta-analysis. J. Dairy Sci. 89:537-548.

Constable, P. D. 1999. Clinical assessment of acid-base status. Strong ion difference theory. Vet. Clin. North Am. Food Anim. Pract. 15:447-471.

Constable, P. D. 2000. Clinical assessment of acid-base status: Comparison of the Henderson-Hasselbalch and strong ion approaches. Vet. Clin. Pathol. 29:115-128.

De Groot, Th., and J. H. Aafjes. 1960. On the constancy of creatinine excretion in the urine of the dairy cow. Br. Vet. J. 116:409-418.

Delaquis, A. M., and E. Block. 1995a. The effects of changing ration ingredients on acid-base status, renal function, and macromineral metabolism. J. Dairy Sci. 78:2024-2039.

Delaquis, A. M., and E. Block. 1995b. Dietary cation-anion difference, acid-base status, mineral metabolism, renal function, and milk production of lactating cows. J. Dairy Sci. 78:2259-2284.

Dhiman, T. R., and L. D. Satter. 1997. Effect of ruminally degraded protein on protein available at the intestine assessed using amino acid concentrations. J. Anim. Sci. 75:1674-1680.

Erdman, R. A. 1988. Dietary buffering requirements of the lactating dairy cow: A review. J. Dairy Sci. 71:3246-3266.

Escobosa, A., C. E. Coppock, L. D. Rowe, Jr., W. L. Jenkins, and C. E. Gates. 1984. Effects of dietary sodium bicarbonate and calcium chloride on physiological responses of lactating dairy cows in hot weather. J. Dairy Sci. 67:574-584.

Fredeen, A. H., E. J. DePeters, and R. L. Baldwin. 1988. Effects of acid-base disturbances caused by differences in dietary fixed ion balance on kinetics of calcium metabolism in ruminants with high calcium demand. J. Anim. Sci. 66:174-184.

Galyean, M. L. 1996. Protein levels in beef cattle finishing diets: Industry application, university research, and systems results. J. Anim. Sci. 74:2860-2870.

Goff, J. P., R. L. Horst, F. J. Mueller, J. K. Miller, G. A. Kiess, and H. H. Dowlen. 1991. Addition of chloride to a prepartal diet high in cations increases 1,25-dihydroxyvitamin D response to hypocalcemia preventing milk fever. J. Dairy Sci. 74:3863-3871.

Guder, W. G., D. Haussinger, and W. Gerok. 1987. Renal and hepatic nitrogen metabolism in systemic acid base regulation. J. Clin. Chem. Clin. Biochem. 25:457-466.

Gustafsson, A. H., and D. L. Palmquist. 1993. Diurnal variation of rumen ammonia, serum urea, and milk urea in dairy cows at high and low yields. J. Dairy Sci. 76:475-484.

Haussinger, D. 1990. Nitrogen metabolism in liver: Structural and functional organization and physiological relevance. Biochem. J. 267:281-290.

Hu, W., and M. R. Murphy. 2004. Dietary cation-anion difference effects on performance and acid-base status of lactating dairy cows: A meta-analysis. J. Dairy Sci. 87:2222-2229.

$\mathrm{Hu}$, W., and M. R. Murphy. 2005. Statistical evaluation of early- and mid-lactation dairy cow response to dietary sodium bicarbonate addition. Anim. Feed Sci. Technol. 119:43-54.

Huber, T. L. 1976. Physiological effects of acidosis on feedlot cattle. J. Anim. Sci. 43:902-909.

Lobley, G. E. 1992. Control of metabolic fate of amino acids in ruminants: A review. J. Anim. Sci. 70:3264-3275.

Lobley, G. E., S. O. Hoskin, and C. J. McNeil. 2001. Glutamine in animal science and production. J. Nutr. 131:2525S-2531S.

Mees, D. C., N. R. Merchen, and C. J. Mitchel. 1985. Effects of sodium bicarbonate on nitrogen balance, bacterial protein synthesis and sites of nutrient digestion in sheep. J. Anim. Sci. 61:985-994.

Murphy, M. R. 1982. Analyzing and presenting $\mathrm{pH}$ data. J. Dairy Sci. 65:161-163. 
Murphy, M. R. 1992. Water metabolism of dairy cattle. J. Dairy Sci. 75:326-333.

Murphy, M. R., and J. S. Zhu. 1997. A comparison of methods to analyze particle size as applied to alfalfa haylage, corn silage, and concentrate mix. J. Dairy Sci. 80:2932-2938.

Oetzel, G. R. 2002. The dietary cation-anion difference concept in dairy cattle nutrition: possibility and pitfalls. Pages 198-208 in Recent Developments and Perspectives in Bovine Medicine: XXII World Buiatrics Congress. M. Kaske, H. Scholz, and M. Holtershinken, ed. Hannover, Germany.

Oetzel, G. R., J. D. Olson, C. R. Curtis, and M. J. Fettman. 1988 Ammonium chloride and ammonium sulfate for prevention of parturient paresis in dairy cows. J. Dairy Sci. 71:3302-3309.

Patience, J. F. 1990. A review of the role of acid-base balance in amino acid nutrition. J. Anim. Sci. 68:398-408.

Patience, J. F., and R. K. Chaplin. 1997. The relationship among dietary undetermined anion, acid-base, and nutrient metabolism in swine. J. Anim. Sci. 75:2445-2452.

Remer, T. 2000. Influence of diet on acid-base balance. Semin. Dial. $13: 221-226$

Roche, J. R., D. Dalley, P. Moate, C. Grainger, M. Rath, and F. O'Mara. 2003. Dietary cation-anion difference and the health and production of pasture-fed dairy cows. 1. Dairy cows in early lactation. J. Dairy Sci. 86:970-978.

Roche, J. R., S. Petch, and J. K. Kay. 2005. Manipulating the dietary cation-anion difference via drenching to early-lactation dairy cows grazing pasture. J. Dairy Sci. 88:264-276.

Sanchez, W. K., and D. K. Beede. 1996. Is there an optimal cationanion difference for lactation diets? Anim. Feed Sci. Technol. 59:3-12.

Sanchez, W., J. Giesy, and L. Griffel. 2000. Adjustment of DCAD may improve performance. Feedstuffs 72:11-13.

SAS Institute. 2001. SAS system software: Release 8.2 (TS2M0). SAS Institute Inc., Cary, NC.

Schonewille, J. T., A. T. Van't Klooster, A. Dirkzwager, and A. C. Beynen. 1994. Stimulatory effect of an anion (chloride)-rich ration on apparent calcium absorption in dairy cows. Livest. Prod. Sci. 40:233-240.

Swenson, M. J. 1993. Physiological properties and cellular and chemical constituents of blood. Pages 22-48 in Duke's Physiology of Domestic Animals. 11th ed. M. J. Swenson and W. O. Reece, ed. Cornell Univ. Press, Ithaca, NY.

Trenkle, A. 1979. The relationship between acid-base balance and protein metabolism in ruminants. Pages $146-157$ in Regulation of Acid-Base Balance. W. H. Hale and P. Meinhardt, ed. Church and Dwight Co., Inc., Piscataway, NJ.

Tucker, W. B., G. A. Harrison, and R. W. Hemken. 1988. Influence of dietary cation-anion balance on milk, blood, urine, and rumen fluid in lactating dairy cattle. J. Dairy Sci. 71:346-354.

Tucker, W. B., J. F. Hogue, D. F. Waterman, T. S. Swenson, Z. Xin, R. W. Hemken, J. A. Jackson, G. D. Adams, and L. J. Spicer. 1991. Role of sulfur and chloride in the dietary cation-anion balance equation for lactating dairy cattle. J. Anim. Sci. 69:1205-1213.

Vagnoni, D. B., and G. R. Oetzel. 1998. Effects of dietary cationanion difference on the acid-base status of dry cows. J. Dairy Sci. 81:1643-1652.

Wang, C., and D. K. Beede. 1992. Effects of ammonium chloride and sulfate on acid-base status and calcium metabolism of dry Jersey cows. J. Dairy Sci. 75:820-828.

Welbourne, T. C., D. Childress, and G. Givens. 1986. Renal regulation of interorgan glutamine flow in metabolic acidosis. Am. J. Physiol. 251:R859-R866.

West, J. W., K. D. Haydon, B. G. Mullinix, and T. G. Sandifer. 1992. Dietary cation- anion balance and cation source effects on production and acid-base status of heat-stressed cows. J. Dairy Sci. 75:2776-2786.

West, J. W., B. G. Mullinix, and T. G. Sandifer. 1991. Changing dietary electrolyte balance for dairy cows in cool and hot environments. J. Dairy Sci. 74:1662-1674.

Wildman, C. D., J. W. West, and J. K. Bernard. 2003. Effect of dietary cation-anion difference and crude protein content on milk yield and blood metabolites of lactating dairy cows during hot weather. J. Dairy Sci. 86(Suppl. 1):216-217. (Abstr.) 